\title{
Digital Modeling Phenomenon of Surface Ground Movement
}

\author{
Ioan VOINA ${ }^{1}$, Maricel PALAMARIU ${ }^{2}$, Iohan NEUNER ${ }^{1}$, Tudor SĂLĂGEAN ${ }^{3 *}$, Dumitru ONOSE ${ }^{1}$, Mircea \\ ORTELECAN $^{3}$, Anca Maria MOSCOVICI ${ }^{4}$ and Mariana CĂLIN ${ }^{5}$ \\ ${ }^{1}$ Department of Topography and Cadastre, Technical University of Construction Bucharest \\ ${ }^{2}$ Department of Exact Sciences and Engineering, "1 Decembrie 1918" University of Alba Iulia. \\ ${ }^{3}$ Department of Land Measurements and Exact Sciences, University Of Agricultural Sciences and \\ Veterinary Medicine Cluj-Napoca \\ ${ }^{4}$ Department of Land Measurements and Cadastre, Politehnica University Timişoara \\ ${ }^{5}$ Department of Mathematics, Physics and Land Measurements, University Of Agronomic Sciences and \\ Veterinary Medicine Bucharest \\ *)Corresponding author, e-mail: tudor.salagean@usamvcluj.ro
}

BulletinUASVM Horticulture 73(2) / 2016

Print ISSN 1843-5254, Electronic ISSN 1843-5394

DOI:10.15835/buasvmcn-hort:12363

\begin{abstract}
With the development of specialized software applications it was possible to approach and resolve complex problems concerning automating and process optimization for which are being used field data. Computerized representation of the shape and dimensions of the Earth requires a detailed mathematical modeling, known as "digital terrain model". The paper aims to present the digital terrain model of Vulcan mining, Hunedoara County, Romania. Modeling consists of a set of mathematical equations that define in detail the surface of Earth and has an approximate surface rigorously and mathematical, that calculated the land area. Therefore, the digital terrain model means a digital representation of the earth's surface through a mathematical model that approximates the land surface modeling, which can be used in various civil and industrial applications in. To achieve the digital terrain model of data recorded using linear and nonlinear interpolation method based on point survey which highlights the natural surface studied. Given the complexity of this work it is absolutely necessary to know in detail of all topographic elements of work area, without the actions to be undertaken to project and manipulate would not be possible. To achieve digital terrain model, within a specialized software were set appropriate parameters required to achieve this case study. After performing all steps we obtained digital terrain model of Vulcan Mine. Digital terrain model is the complex product, which has characteristics that are equivalent to the specialists that use satellite images and information stored in a digital model, this is easier to use.
\end{abstract}

Keywords: Digital Terrain Model (DTM), exploitation, surveying

\section{INTRODUCTION}

With the development of specialized software applications it was realized the opportunity to address and resolve complex problems concerning automating and process optimization are being used field data. Computerized representation of the shape and dimensions of the Earth requires a detailed mathematical modeling, known as "digital terrain model". Digital modeling of the land is a set of techniques that give an elevation numerical model (Digital Elevation Model) (Hengl et al., 2003; Hengl, 2004). Once completed numerical elevation models, they find use as input data for the derivation of topographic attributes (Wilson and Gallant, 2000), of geomorphometry parameters, of morphometric variables (Shary et al., 2002) or general information (Martinoni, 2002) on that land (Terente, 2008).

Digital terrain model is the complex product, which has characteristics that are equivalent 


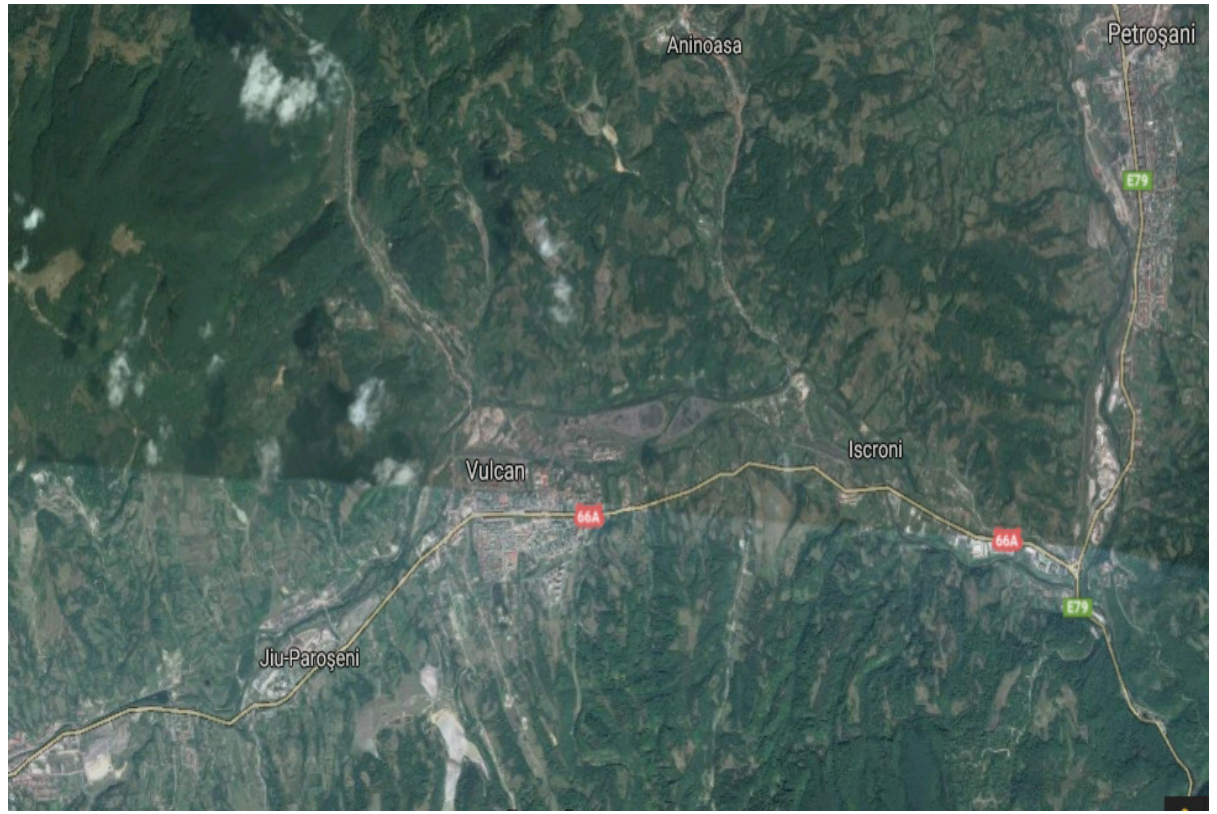

Fig. 1. Orthophotomap town of Vulcan, Hunedoara County, Romania. Source: https://www.google.com.co/maps/

to the specialists that use satellite images and information stored in a digital model, this is easier to use.

Elevation data sources are data from altitude determination of the Earth's surface. Currently there are five main sources of altitude data (Hengl et al., 2003): topographic surveys; aerial photographs; maps, real topographical plans, aerial laser scanning and radar or stereoscopic satellite images.

The objective studied is located in the Vulcan town, a town situated at the foothills of Vâlcan Mountains, the city being crossed by the national road 66A, which connects the Vulcan and Brazi Valley. Vulcan city is at a distance of about 12 $\mathrm{km}$ from Petrosani and about $110 \mathrm{~km}$ from Deva (Hunedoara county seat). Currently the town Vulcan covers an area of 8731 ha and has two localities: Dealu Babii (village located in the north on DJ 66 Vulcan-Merisor) and Jiu-Paroșeni (village located in the western part of the city, on Route 66A Petroşani -Uricani). Vulcan town has beennamed after Vâlcan gorge found in the Valcan mountains, crossing gorge between the Jiu Valley and northern Oltenia. Vulcan town is bordered by city Aninoasa at east, by Lupeni city at west, Bănița village at north and Gorj county to the south. The second largest town of the Jiu Valley, after Petrosani, village crossed from west to east by West Jiu River, Vulcan is one of the most important resources of coal deposit (Fig. 1).

The paper aims to present the digital terrain model of mining Vulcan, Hunedoara County, Romania.

Displacements and deformations of the land in this case had a slow evolution, but continue in time so that, at present, can be seen easily, even without specific means of measurement.

Through this research we aimed to determine the digital terrain model using existing tracking landmarks on the surface of the above mentioned objective having as altimetric underground reference a layer of the coal mining deposit.

\section{MATERIALS AND METHODS}

This step involves the derivation of the numerical model parameters land of their altitudinal distribution analysis and cartographic methods (maps, sections, block diagrams) and statistics (frequency histogram). They differ in (Wilson and Gallant, 2000): primary parameters, those derived directly from the altitude of DEM's and secondary parameters which serve to describe geomorphological processes (Marchi and Fontana, 2005).

The quality and accuracy parameters depend mostly on the abundance and variety of topographic measurements in displacements and deformation tracking stations under the influence of 


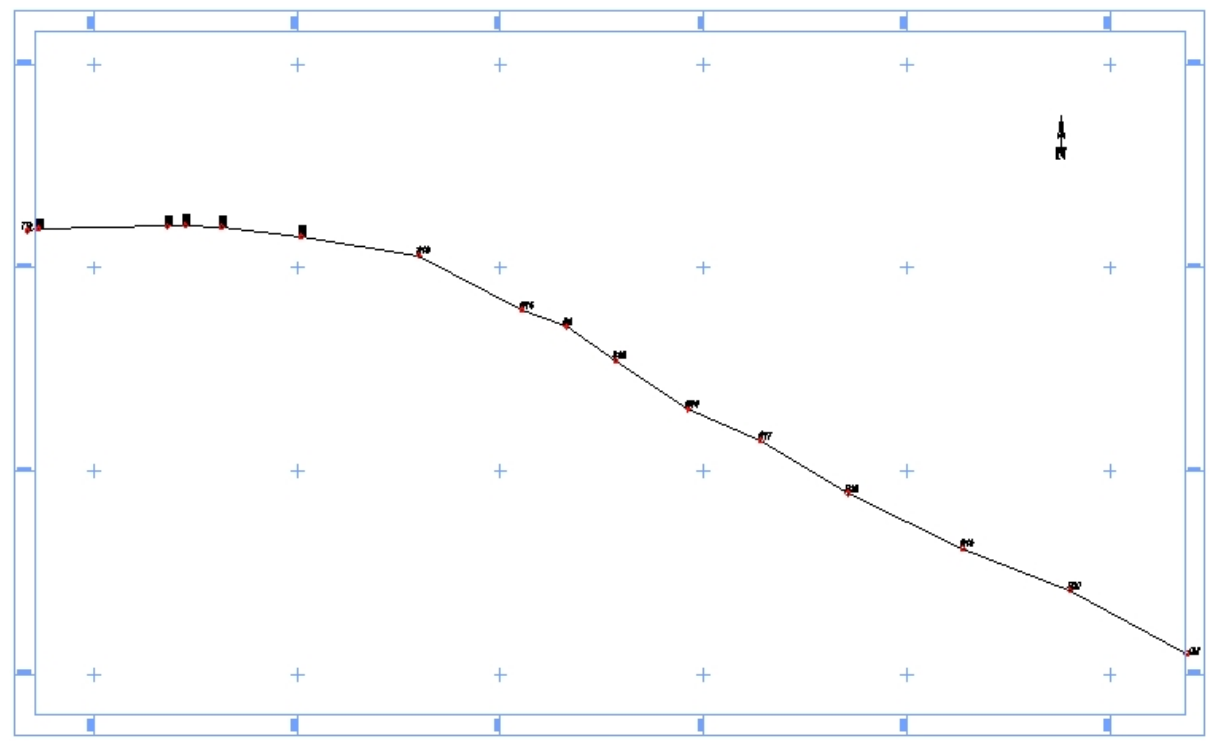

Fig. 2. Topographical layout of the tracking network

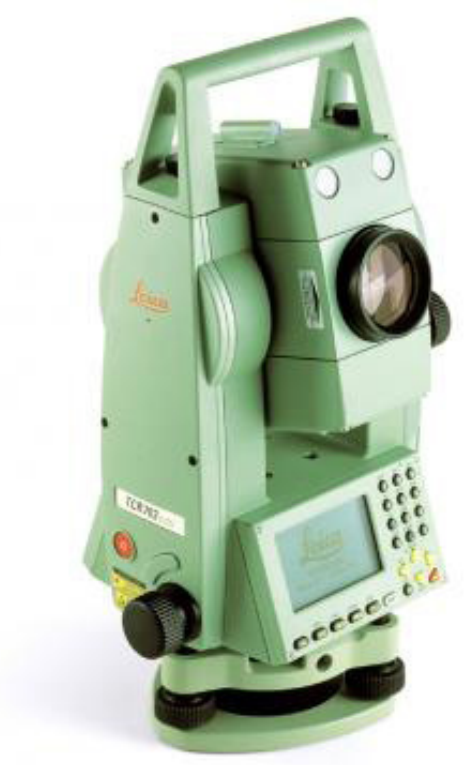

Fig. 3. Total station

underground space mined. The requirements for the topographic measurement results are related to the accuracy of the measurements made, the intervals of repetition of measurement and other factors.

\section{RESULTS AND DISCUSSIONS}

In order to monitor earth's surface displacements were used supported traverse at both ends (Fig. 2) using fixed landmarks CN, S20, B6 and TG, where the radiated method were determined the mobile landmarks: B1, B2, B3, B4, B5, S13, S14, S15, S16, S17, S18 (Table 2).

For the determining of the value required for performing this study, was used a total station (Fig. 3).

Materials and documents which formed the basis of research conducted and played in this paper were purchased from the Hunedoara Energy Complex, formerly the National Coal Company S.A. Petrosani, Romania.

Given the complexity of this work is absolutely necessary detailed knowledge of all elements 
Tab. 2. Inventory of the coordinated, the comparative data obtained by Surveying period 6 July 2008- 11July 2009.

\begin{tabular}{cccccccc}
\hline \multicolumn{3}{c}{ Inventory of the coordinated, the comparative data obtained by Surveying period 2008-6 July 11 July 2009., } \\
\multicolumn{3}{c}{$\begin{array}{c}\text { LOC. VULCAN, JUD. HUNEDOARA, ROMANIA } \\
\text { 06 JULY 2008 }\end{array}$} \\
$\begin{array}{ccccccccc}\text { measuring points } \\
\text { 11 JULY 2009 }\end{array}$ \\
\hline CN & 79010.198 & 31737.769 & 662.712 & CN & 79010.198 & 31737.769 & 662.743 \\
\hline S20 & 79041.456 & 31680.317 & 655.632 & S20 & 79041.456 & 31680.317 & 655.584 \\
\hline S19 & 79061.943 & 31627.745 & 650.027 & S19 & 79061.943 & 31627.745 & 649.902 \\
\hline S18 & 79088.801 & 31570.952 & 642.567 & S18 & 79088.801 & 31570.952 & 642.526 \\
\hline S17 & 79114.862 & 31528.291 & 638.288 & S17 & 79114.862 & 31528.291 & 638 \\
\hline S16 & 79130.234 & 31492.439 & 636.060 & S16 & 79130.234 & 31492.439 & 635.688 \\
\hline S15 & 79154.390 & 31456.658 & 634.073 & S15 & 79154.390 & 31456.658 & 633.813 \\
\hline S14 & 79179.254 & 31410.753 & 631.983 & S14 & 79170.966 & 31432.196 & 633.003 \\
\hline S13 & 79206.153 & 31359.951 & 632.168 & S13 & 79179.254 & 31410.753 & 631.409 \\
\hline B1 & 79170.966 & 31432.196 & 633.299 & B1 & 79206.153 & 31359.951 & 630.7 \\
\hline B2 & 79215.347 & 31302.082 & 632.748 & B2 & 79215.347 & 31302.082 & 631.1 \\
\hline B3 & 79220.131 & 31262.863 & 633.546 & B3 & 79220.131 & 31262.863 & 631.802 \\
\hline B4 & 79220.930 & 31244.958 & 633.546 & B4 & 79220.930 & 31244.958 & 632.554 \\
\hline B5 & 79220.325 & 31236.180 & 633.479 & B5 & 79220.325 & 31236.180 & 632.878 \\
\hline B6 & 79219.088 & 31172.499 & 633.934 & B6 & 79219.088 & 31172.499 & 633.85 \\
\hline TG & 79218.044 & 31167.074 & 634.049 & TG & 79218.044 & 31167.074 & 634.005 \\
\hline
\end{tabular}

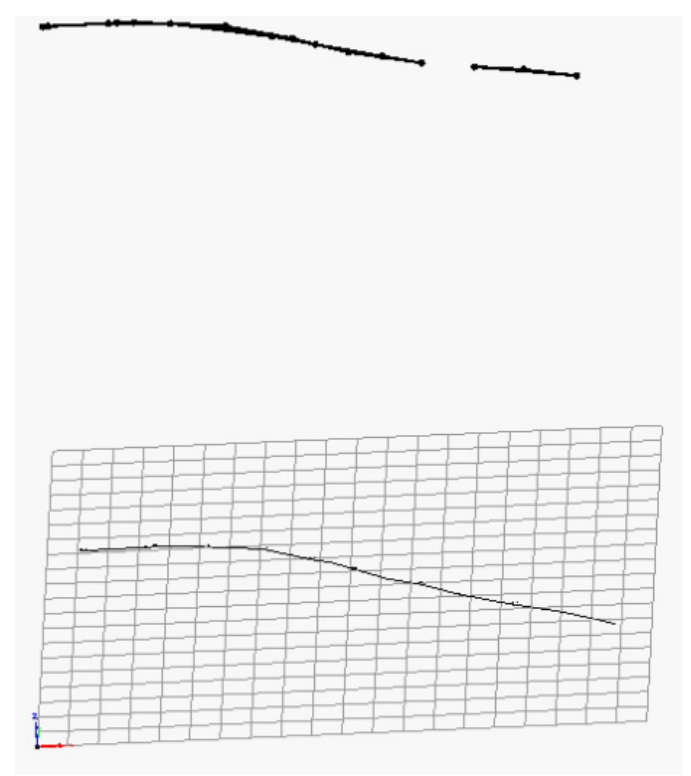

Fig. 4. Rendering the digital model of the intended purpose

topographic work area, without which actions to be taken to design and workmanship would not be possible. To achieve digital terrain model, within specialized software were set appropriate parameters necessary to achieve this case study (Fig. 4 and 5). After performing all stages of digital terrain model we obtained the land area where they are located landmark of mining Vulcan, Hunedoara County, Romania.

\section{CONCLUSION}

Among the areas where digital terrain model can have an immediate application shall include: analysis of telecommunications systems (with 


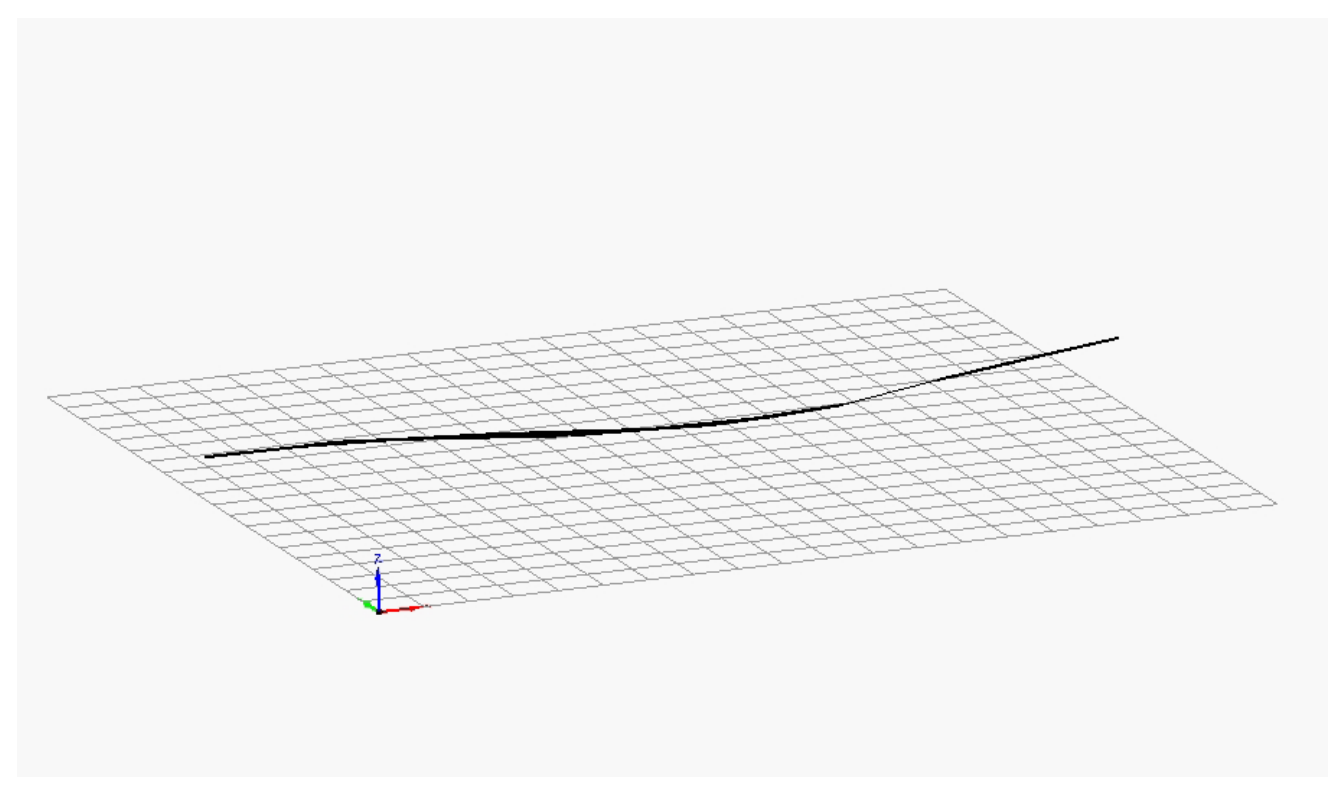

Fig. 5. Representing the digital terrain model for objective study.

cross sections of land, analysis of propagation, transmission networks and other specific applications), design in pipeline networks (eg adduction water), command and control various systems, military, video games and in all other areas that require knowledge of altitude information at different points of a surface.

Digital terrain model and related technology is a basic tool of a Geographical Information System (GIS) that provides a more real and more complex the world around allowing you to manage large volumes of data and better management of human activities for maintaining the vitality world economy and environmental quality.

\section{REFERENCES}

1. Hengl TG, Ruber S, Shresta DP (2003). Digital Terrain Analysis in ILWIS. Lecture notes. ITC -International Institute for Geo-Information Science and Earth Observation, 2003 Digital Terrain Analysis in ILWIS
Lecture notes. ITC-International Institute for GeoInformation Science and Earth Observation.

2. Hengl TG (2004). Reduction of errors in digital terrain parameters used in soil-landscape modelling. International Journal of Applied Earth Observation and Geoinformation 5 .

3. Marchi L, Fontana G (2005). GIS morphometric indicators for the analysis of sediment dynamics in mountain basins. Environmental Geology 48: 218-228.

4. Martinoni D (2002). Models and Experiments for Quality Handling in Digital Terrain Modelling. PhD Thesis, University of Zurich.

5. Terente M (2008). Modelarea și analiza digitală a terenului. $\mathrm{Cu}$ aplicații în bazinul montan al Teleajenului , Teza de doctorat, Facultatea de Geografie a Universității din București.

6. Shary P, Sharaya L, Mitusova A (2002). Fundamental quantitative methods of land surface analysis. Geoderma 107.

7. Wilson JP and Gallant C (2000). Terrain analysis: principles and applications. New York: John Wiley \& Sons, Ltd. 